Bull. Fac.Agric.,Cairo Univ. 63:432-438 (2012)

\title{
MORPHOLOGICAL STUDIES ON LEAF, POLLEN GRAIN AND SEED \\ OF GENUS Oenothera L. IN EGYPT BY USING \\ SCANNING ELECTRON MICROSCOPE "SEM"
}

(Received: 10.9.2012)

\author{
By \\ H. S. Abd - El Maksoud \\ Flora and Phyto-taxonomy Researches Department, Horticultural Research Institute, \\ Agricultural Research Center, Giza, Egypt..
}

\begin{abstract}
This study was performed on three species of the genus Oenothera in Egypt. These species are; $O$. biennis, $O$. drummondii and $O$. speciosa. The aim of this study was to distinguish the similarity and dissimilarity between these species. This study includes a number of taxonomic evidences and characters to establish the relationships among the above mentioned species. These characters were; 1) the morphological descriptions of the whole plants representing these species, 2) morphological descriptions and Scanning Electron Microscope (SEM) survey on the leaf, pollen grain and seed surfaces of the studied species. .Then proposed keys were designed.
\end{abstract}

Key words: botanical key, leaf morphology, Oenothera, pollen grain, morphology, seed morphology, SEM, taxonomy.

\section{INTRODUCTION}

Oenothera is a genus of about 125 species of annual, biennial and perennial herbaceous flowering plants, native to North and South America. It is the type genus of the family Onagraceae, the Evening Primrose Family. (Quattrocchi, 2000). Leaf alternate, flower actiomorphic, axillary, solitary, sometimes forming a leafy terminal spike. Sepals 4, often caducous, usually strongly reflexed. Petals 4, yellow, rarely white or pink, abovate or obcordate, with or without a short claw. Stamens 8, equal or the inner ones shorter. Overay 4-celled, cylindrical; stigma deeply 4-cleft into linear lobes or rarely capitate. Capsule splitting loculicidally into 4 valves. Seed without a tuft of hairs. (Zohary, 1987).

The size and shape of juvenile leaves in particular are important taxonomic charaters in Eucalyptus (Pryor 1976 ) with closely related species being differentiated by these traits (e.g., Phillips and Reid 1980 and Potts and Reid 1985). Ostroumove (1990) studied the stomata types on leaves of some species belonging to the tribes Coriandreae and Scandiceae (Umbelliferae) in relation to taxonomy. Szujko-Lacza (1994) studied the leaf characters of Coriandrum sativum. El-Khanagry (2003) purposed a key to identify 49 species of grasses belonging to 33 genera by using vegetative characters of leaves as well as trichomes and cuticular ornamentations. However, the gross morphological characters of the leaf have been used for identification purposes. With increased sophistication of classification systems it has become increasingly important to have more elaborative means for identification. The leaf has not lost its importance as a taxonomic tool but rather has proved to be more useful when a full understanding of all its characteristics are known and appreciated.

Pollen grain shapes are described, as well as markings, size, color, stickiness, abundance and other features. It is found that, in general, the shape and size of grains in the various genera exceptions are the thread-shaped pollen grains of some eelgrass) and in aspect: round, ovale, disc or bean-shaped and somtimes filamentous. The natural color is mostly white, cream, yellow or orange. The texture of the cell 
wall shows also great variations, from smooth to spiky .(Maxy, 1925). Defining sculpture of those forms have been described only the basis of observations using TEM and SEM (Basil, 1995). Pollen grains of various species can vary quite a lot in size (from about 10 to nearly 100 micrometer) and shape; round, ovale, disc or bean-shaped and somtimes filamentous. The natural color is mostly white, cream, yellow or orange. The texture of the cell wall of pollen grain shows also great variations, from smooth to spiky (Thanikaimoni and Van derHam, 1999).

Fossil pollen grains are distinguished primarily by their form and their surface sculpture furnishing a Key to distinugsh. 17 basic pollen classes.(Christopher 1979).

Pollen of 110 species from 18 genera in the Portulacaceae has been examined by light and scanning electron microscopy, and a representative number by transmission electron microscopy. (Bio 1992). Pollen grains of the neotropical subtribe Cuspariinae (Rutaceae) were examined by LM, SEM and TEM. The pollen morphology of this subtribe is very diverse. (Cynthia and Jacquelyn, 1993).

The great variations in the morphology and the different ornamentations of the seed coat support the study of taxa delimitation and may solve and facilitate many taxonomic problems. Netolizky (1926) confirmed also that the morphology of seed coat surface should be the principles of natural classification of the flowering plants. Vaughan (1968) suggested that the structure of the mature seeds, especially the coat structure is considered the more taxonomic useful information.

Surface sculpturing may aid in solving problems of identity or relationship concerning taxa at various levels (Werker, 1997). The SEM examinations of seed surface features could be applied in taxonomy and there are many characters (e.g. seed coat) that could be used to characterize groups of related species, genera or taxonomic categories up to the sub-family levels. Some characters of the micromorphology and orientation of epicuticular wax crystalloid are surprisingly of high systematic significance.(Barthlott, 1981 ). More detailed structural information about seeds are obtained by using the Scanning Electron Microscope. However, Yeh and Kakuma (1990) suggested that seed characters; colour, coat patterns, shape, size, outer arils and hilum lead to better criteria for species identification and support the taxonomical positions of taxa.

The aim of this study was to distinguish the taxonomic relationship among three species of genus Oenothera in Egypt namely $O$. biennis, $O$. drummondii and $O$. speciosa.

\section{MATERIALS AND METHODS}

Three species of the genus Oenothera were studied (Table 1). The fresh leaves, pollen grain and seeds of each species were used. These species were planted in the Medicinal and Aromatic Plants Research Department, Horticultural Research Institute, Agricultural Research Center, Dokki, Giza. The detailed surface scan features were examined by using Scanning Electron Microscope (SEM) with different magnifications. Scanning was carried by JEOL- JSM T 100 Model Scanning Electron Microscope, Central Laboratory, National Information and Documentation Center (NIDoC), Dokki, Giza, Egypt.

\section{RESULTS AND DISCUSSION}

The results are gathered according to the following aspects: macromorphological and Scanning Electron Microscope (SEM) descriptions of leaf (upper and lower surfaces), pollen grain and seed surfaces for each species.

Keys were proposed to the distinguish

Table (1): The studied species and the collection regions.

\begin{tabular}{|c|c|c|c|}
\hline No. & Species & Habit & \multicolumn{1}{|c|}{ Region } \\
\hline 1. & Oenothera biennis L. & Cultivated & $\begin{array}{l}\text { Experimental field of Faculty of Agriculture, } \\
\text { Cairo University and Agricultural Museum, } \\
\text { Giza. }\end{array}$ \\
\hline 2. & $\begin{array}{c}\text { Oenothera drummondii } \\
\text { Hook. }(=\text { O. } \text { humifusa } \text { Nutt.) }\end{array}$ & Wild & $\begin{array}{l}\text { North Manzala Lake- near Boughaz } \\
\text { El Gameel. }\end{array}$ \\
\hline 3. & Oenothera speciosa Nutt. & Cultivated & Orman garden and Agricultural Museum, Giza. \\
\hline
\end{tabular}


the studied species based on morphological characters of the whole plants and macro and micromorphological characters of the leaf and seed of the studied species.

\section{1) Oenothera biennis $\mathbf{L}$.}

Biennial, stem erect growing to $30-200 \mathrm{~cm}$ tall, ramified only above, dense leafy, hairy, glandularly downy. Inflorescence erect. Flowers large, yellow, $2.5-5 \mathrm{~cm}$ in diameter, grow all along the stalks. Sepla - apices terminal, slender, appressed to one another in bud. Petals four, hermaphrodite. The fruit is a capsule 2$3.2 \mathrm{~cm}$ long and $4-6 \mathrm{~mm}$ broad, ovate, tapering above, numerous seeds, released when the capsule splits into four sections at maturity.

\section{i) Leaf}

Lanceolate or oblong- lanceolate, 5$19 \mathrm{~cm}$ long and $1-5 \mathrm{~cm}$ broad, produced in a tight rosette in the first year, and spirally on the stem in the second year, green colour, covered with short hairs on both surfaces. Upper epidermis has stomatal type; anomocytic with semidepressed level and with scrobiculate sculpture pattern. Lower epidermis has anomocytic stomatal type with superficial and semiraised level and with ruminate sculpture pattern. Trichomes; non-glandular (vinca) and glandular (vasaka), tuberculate ornamentation.(Figs. 1 and 2).

\section{ii) Pollen grain}

Pollen grain free, more than one aperture, tricolporate, normapolles - type; plicapollis. The zone of germination pores depressed. Tectum glebulate.(Fig. 4).

\section{iii) Seed}

Seed numerous $1-4 \times \quad 0.7-1 \quad \mathrm{~mm}$ in dimensions, released when the capsule splits into four sections at maturity. Variously angled, often with a rounded side, or angular, spindle shaped to flattishoblong, or angular - lanceolate; smooth to rough surfaced, yellow - brown to dark purplish brown, surface dull, glabrous, fine waved. Colliculate epidermal cell walls. Depressed anticlinal walls and usually 5-6 gonal, raised boundaries, straight with irregular cannels. Outer periclinal walls are convex or concave with delicate furrows. Hilum inconspicuous, basal, rough and hairy. (Fig. 3).

2) Oenothera drummondii Hook. ( = O. humifusa Nutt.)

Perennial, pubescent herb, shrubby, up

to $80 \mathrm{~cm}$ tall. Stem many,erect or procumbent, much branched all along. Flower 5- $7 \mathrm{~cm}$, across. Sepals 2-3 cm, reflexed, linear- lanceolate. Petals $2.5-3$ $\mathrm{cm}$,bright yellow, broadly obovate. Stigma deeply 4 cleft. Capsule $2.5-5 \mathrm{~cm}$ long and 2 - $4 \mathrm{~mm}$ broad, lanceolate, obtuse 4 angled.

\section{i) Leaf}

Lanceolate - oblong, 3-6 x 1-2 cm, tapering gradually or abruptly to a short petiol, acute or obtuse, entire or slightly toothed, densely soft- pubescent covered with short white hairs, silvery green. Upper epidermis has stomatal type; anomocytic with superficial level. Ruminate sculpture pattern of upper epidermis. Lower epidermis has anomocytic stomatal type with depressed level. alveolate sculpture pattern. Trichomes; non-glandular (datura ) and glandular (vasaka), smooth ornamentation.(Fig. 1).

\section{ii) Pollen grain}

Pollen grain free, more than one aperture, tricolporate, normapolles - type; semioculopollis. The zone of germination pores raised. Tectum glebulate-favulariate. (Fig. 4).

iii) Seed

Numerous fusiform seed / capsule. 1$1.4 \times 0.4-0.7 \mathrm{~mm}$ in dimensions, often with a rounded side, oblong shaped, smooth surfaced, cream to brown, surface glossy, glabrous. Reticulate epidermal cell walls. Raised anticlinal walls and usually 4-5 gonal, slightly raised boundaries and sinuous with irregular cannels. Outer periclinal walls discharged. .Hilum conspicuous, basal, glabrous, smooth. (Fig. $3)$.

\section{3) Oenothera speciosa Nutt.}

Herbaceous, perennial, wildflower, glaborous (smooth) to pubescent stems that grow to $40 \mathrm{~cm}$ in height. Flower single, fourpetaled, cup-shaped flowers on the upper leaf axils, fragrant shell-pink flowers, 1.5-2 x $3-5$ $\mathrm{cm}$ flowers start out white and grow pink as they age. The flower throats, as well as the stigmas and stamens, have a soft yellow color. Capsule $0.5-1.1 \mathrm{~cm}$ long and $2-3 \mathrm{~mm}$ broad, lanceolate, carpophore present.

\section{i) Leaf}

Pubescent, alternate, sessile or petiolate, reaching $1 \mathrm{x} 4 \mathrm{~cm}$. Variable in shape, from linear to obovate, and are toothed or wavymargin, green, base of blad distanced. 

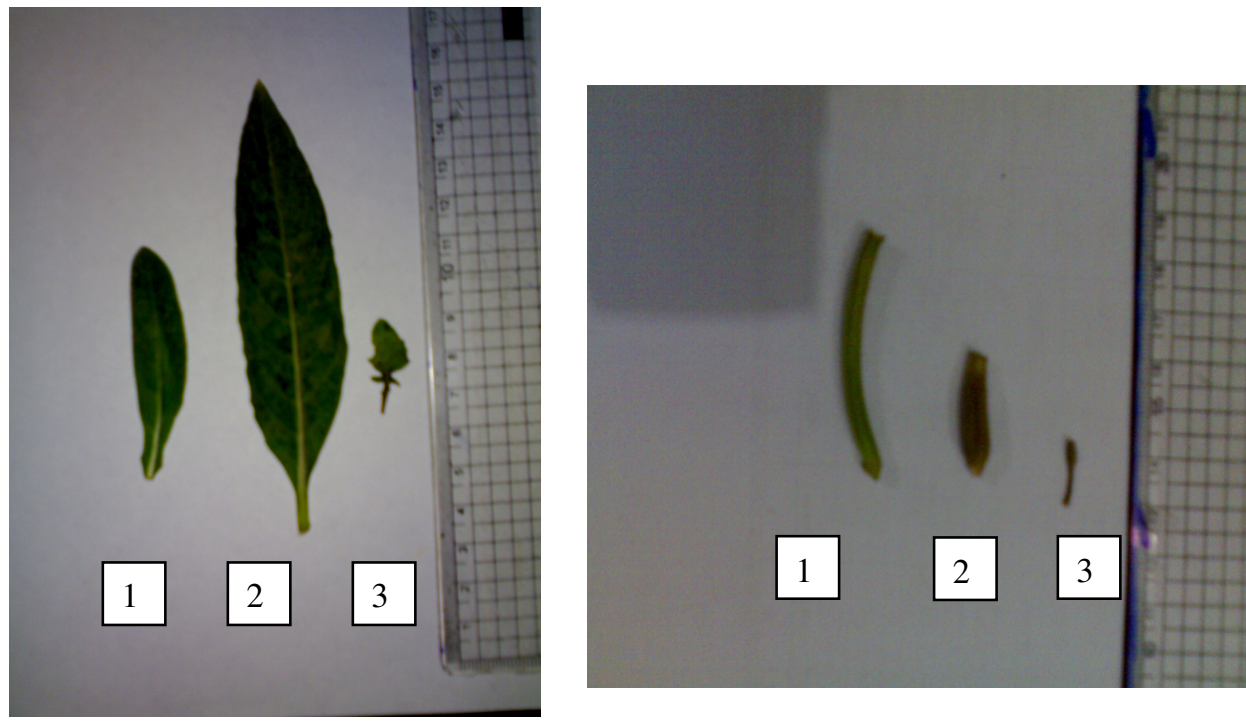

Fig.(1): Shapes of leaf (left) and capsule (right) of the studied species.

1) Oenothera drummondii

2) $O$. biennis

3) O. speciosa

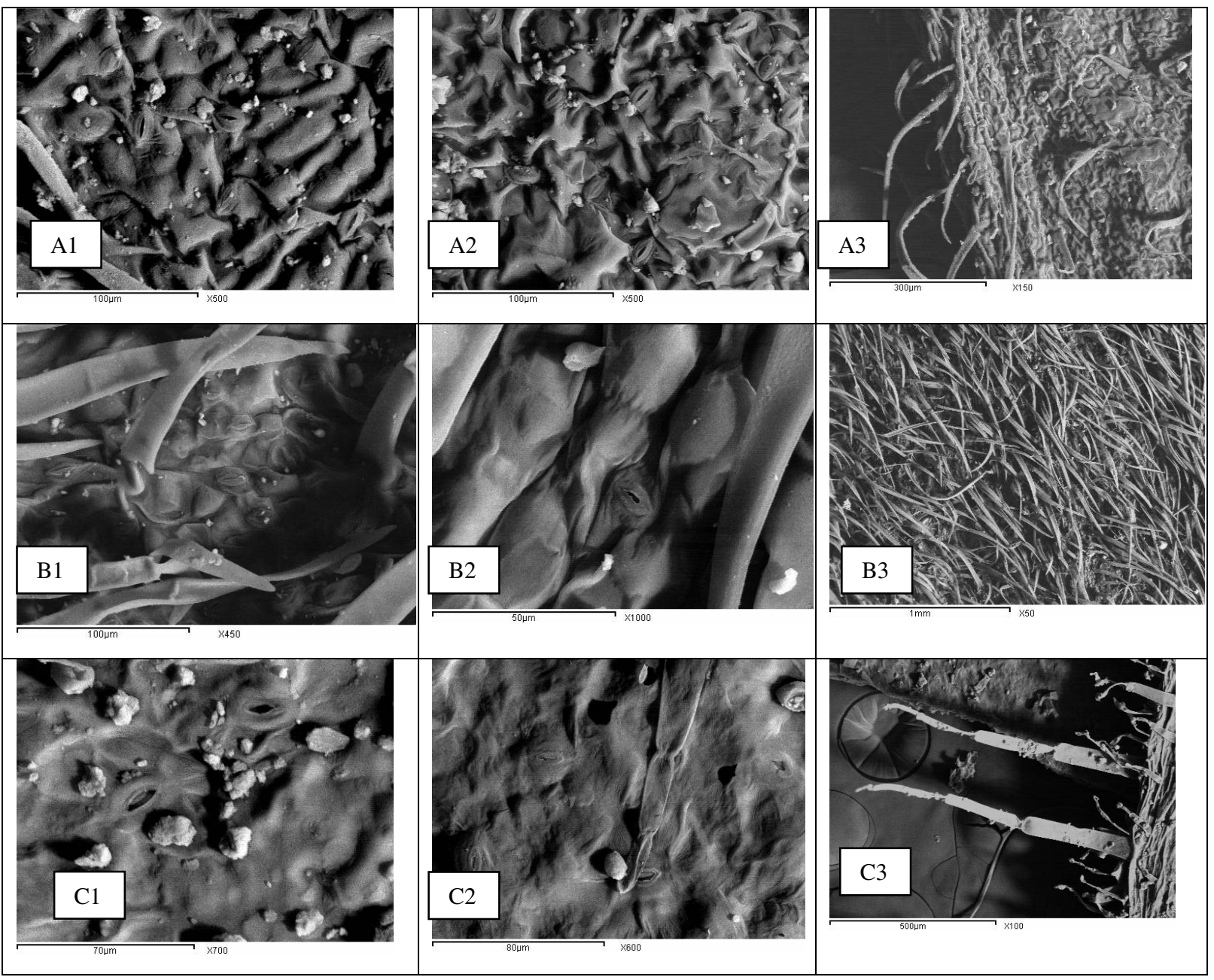

Fig. (2): SEM on leaf epidermis; (1)upper surface,(2) lower surface (3) trichomes
A) Oenothera biennis
B) O. drummondii
C) O. speciosa 


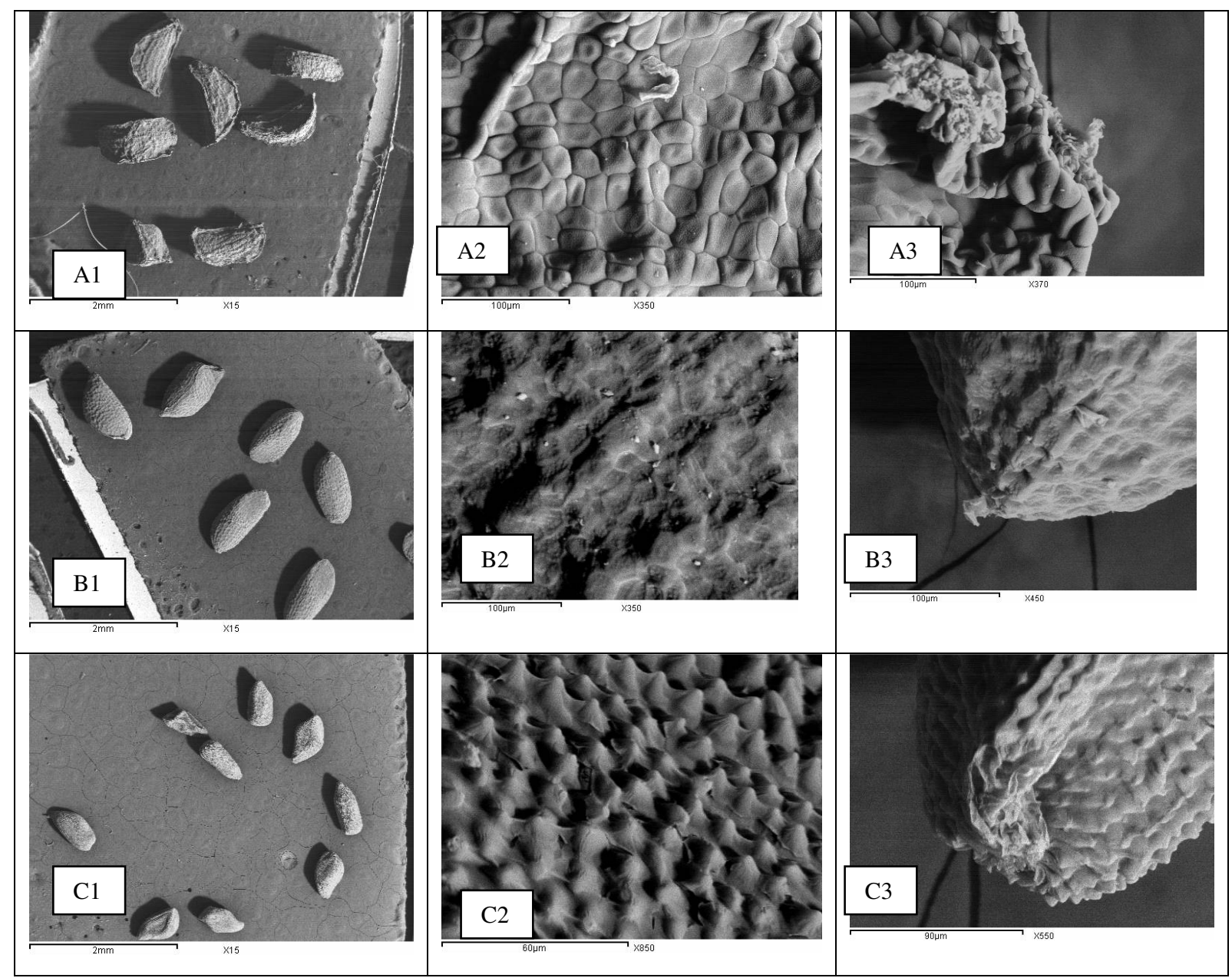

Fig. (3): SEM on seed; shape(1), surface sculpture(2) and hilum(3) of the studied species. A) Oenothera biennis $\quad$ B) O. drummondii $\quad$ C) $O$. speciosa
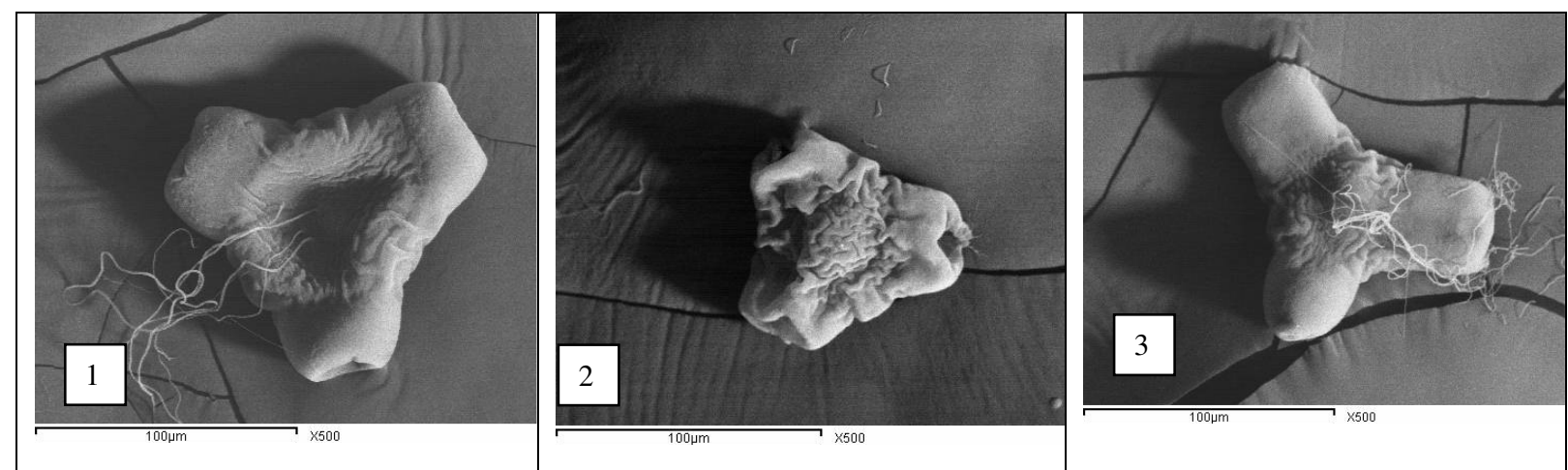

Fig. (4): SEM on pollen grain of the studied species.
1) Oenothera biennis
2) O. drummondii
3) O. speciosa

Upper epidermis has stomatal type; anomocytic with superficial level. Pusticulate sculpture pattern. Lower epidermis has anomocytic stomatal type with depressed level. Pusticulate sculpture pattern. Trichomes; non-glandular (datura) and glandular (belladonna), smooth ornamentation. .(Figs. 1 and 2). ii) Pollen grain

Pollen grain free, more than one aperture, tricolporate, type tricolpite. The zone of germination pores semiraised. Tectum glebulate. (Fig. 4).

iii) Seed

Seed numerous $0.6-1 \times 0.3-0.5 \mathrm{~mm}$ in dimensions, often with a rounded side, ovate 
shaped, smooth surfaced, cream, surface shiny, glabrous. Tuberculate epidermal cell walls. The anticlinal walls elongate in one direction and usually 4 gonal, boundaries raised, straight. Outer periclinal walls convex. Hilum conspicuous, basal, glabrous, smooth. (Fig. 3).

Keys

The following keys were proposed to distinguish and identify the studied species. The skeleton of these keys are based on; 1) the general morphological features of the whole plant of studied species and 2) the macro and micro morphological characters of the seed and leaf.

1) Key based on the morphological characters of the studied species.

\section{A. Flower yellow}

b. Capsule 2-3.2 cmx 4-6 mm, ovate. Biennial,herbaceous........ Oenothera biennis bb. Capsule $2.5-5 \mathrm{~cm}$ x 2-4mm, lanceolate. Peranial, shrubby. ...O. drummondii

AA. Flower pink, herbaceous perennial.The flower throats, as well as the stigmas and stamens, have a soft yellow. Capsule 0.5$1.1 \mathrm{~cm} \times 2-3 \mathrm{~mm}$, lanceolate. Carpophore present............................... O. speciosa

2) Key based on the macro and micro morphological characters of the leaf of the studied species.

A. Leaf small, sessile or petiole, reaching $1 \mathrm{x}$ $4 \mathrm{~cm}$, toothed or wavy-margin, green, base of blade distanced. Pusticulate sculpture pattern of upper and lower epidermis....... . speciosa

AA. Leaf not so.

a. Surface of leaf silvery green, $3-6 \times 1-2$ $\mathrm{cm}$, lanceolate - oblong. Ruminate sculpture pattern of upper epidermis with superficial level of stomata. Lower epidermis alveolate with depressed level of stomata......................... O. drummondii

aa. Surface of leaf green, 5-19 x 1$5 \mathrm{~cm}$, lanceolate or oblong- lanceolate. Scrobiculate sculpture pattern of upper epidermis with semidepressed level of stomata. Lower epidermis ruminate with superficial and semiraised stomatal level......................... O. biennis

3) Key based on the macro and micro morphological of seed of studied species.

A. Seed rounded side

a. Cream to brown, oblong shaped. Reticulate epidermal cell walls. Outer periclinal walls discharged...................... O. drummondii aa. Cream, ovate shaped. Tuberculate epidermal cell walls. Outer periclinal walls are convex................................ O. speciosa AA. Seed variously angled, often with a rounded side, or angular, spindle shaped to flattish- oblong, or angular - lanceolate, yellow - brown to dark purplish brown, surface fine waved. Colliculate epidermal cell walls. Outer periclinal walls are convex or concave with delicate furrows....

O. biennis

\section{REFERENCES}

Barthlott W. (1981). Epidermal and seed surface characters of plants: Systematic applicability and some evolutionary aspects. Nordic Journal of Botany, Copenhagen, Vol. 1: 345-355.

Basil E. Balme (1995). Fossil in situ spores and pollen grains: annotated catalogue. Review of Palaeobotany and Palynology. Vol. 87: 81-323.

Bio L. Nyananyo (1992). Pollen Morphology in the Portulacaceae (Centrospermae) Folia Geobotanica \& Phytotaxonomica Vol. 27, No. 4 , pp. 387-400.

Christopher R. A. (1979) Normapolles and triporate Pollen assemblages from the Raritan and Magothy Formation ( upper cretaceous ) of New Jersey. Palynology. 3: 73-121.

Cynthia M. Morton and Jacquelyn A. Kallunki(1993). Pollen Morphology of the Subtribe Cuspariinae (Rutaceae). Brittonia Vol. 45, No. 4 pp. 286-314.

El-Khanagry S.S.G. (2003). Field key for identification of some Egyptian grasses by vegetative characters. The $2^{\text {nd }}$ Conference of Agriculture \& Biological Research Division, National Research Center, Egypt. Vol. 3: 547-557.

Maxy A. P. (1925). Pollen Morphology as an Index to Plant Relationship. I. Morphology of Pollen. Botanical Gazette Vol. 80, No. 1, pp. 63-73.

Netolizky F. (1926). Anatomic der Angiospermen. Bd. 10 in Hand buch der Pflanzenanatomie.Abt., $2^{\text {nd }}$ Edit. K.Linbauer, Berlin pp. 845.

Ostroumove T.A. (1990). Stomatal types in the Umbelliferae in relation to taxonomy of tribe Conianreae \& Scandiceae. Fedds Report 101 (7-8): 409-416.

Phillips R. L. and Reid J. B. (1980). Clinal variation between Eucalyptus viminalis Labill. and Eucalyptus dalrympleana 
Maiden. Australian Journal of Botany 28: 329-342.

Potts B. M. and Reid J. B. (1985). Variation in the Eucalyptus gnii-archerii complex. 11 The origin of variation . Australian Journal of Botany 33: 519-541.

Pryor L. D. (1976). The biology of Eucalyptus. Edward Arnold, London, U. K. pp82. Quattrocchi, Umberto (2000). CRC World Dictionary of Plant Names. III: M-Q. CRC Press. p. 1860.

Szujko-Lacza J. (1994). Architecture and inner structure of the Coriandram sativum L., Akademial Kiado. Budapest, Prielle Korneliau. pp. 19-35.

Thanikaimoni K. and Van derHam R. W. J.
M.(1999). Eighth bibliographic index to the pollen morphology of Angiosperms. All India Press, Pondichery, Pp 346.

Vaughan J.G. (1968). Seed anatomy and taxonomy. Proc. Linn. Soc., London. 179: 251-255

Werker E. (1997). Seed Anatomy. Gebrvder Borntraeger, Berlin, Germany. pp.359

Yeh M. S. Y. and Kakuma M. (1990). Bambara bean. Tropical Leguminous resources (11). Journal of the Agric. Association of China., 138: 3-15.

Zohary M. (1987). Flora of Palestina., Vol. 2 Text Platanaceae to Umbellifeare, Printed in Israel Academy of Sciences and Humanities. pp. 489. 